\title{
UNCERTAINTY AVOIDANCE AND THE RATE OF BUSINESS OWNERSHIP ACROSS 21 OECD COUNTRIES, 1976-2004
}

Sander Wennekers

Roy Thurik

André van Stel

Niels Noorderhaven
EIM Business and Policy Research, Zoetermeer

Erasmus University Rotterdam, EIM Business and Policy Research, Zoetermeer and Max Planck Institute of Economics, Jena

EIM Business and Policy Research, Zoetermeer, Cranfield University School of Management and Erasmus University Rotterdam

Tilburg University

\section{VERSION: (November 2006) FINAL VERSION}

DOCUMENT: JEE-SI-THUFREY-Wennekers-etal-post-McCann_FINAL2.doc

\begin{abstract}
Persistent differences in the level of business ownership across countries have attracted the attention of scientific as well as political debate. Cultural as well as economic influences are assumed to play a role. This paper deals with the influence of cultural attitudes towards uncertainty on the rate of business ownership across 21 OECD countries. First, the concepts of uncertainty and risk are elaborated, as well as their relevance for entrepreneurship. An occupational choice model is introduced to underpin our reasoning at the macro-level. Second, regression analysis using pooled macro data for 1976, 1990 and 2004 and controlling for several economic variables, yields evidence that uncertainty avoidance is positively correlated with the prevalence of business ownership. According to our model, a restrictive climate of large organizations in high uncertainty avoidance countries pushes individuals striving for autonomy towards selfemployment. Regressions for these three years separately show that in 2004, this positive correlation is no longer found, indicating that a compensating pull of entrepreneurship in countries with low uncertainty avoidance may have gained momentum in recent years. Third, an interaction term between uncertainty avoidance and GDP per capita in the pooled panel regressions shows that the historical negative relationship between GDP per capita and the level of business ownership is substantially weaker for countries with lower uncertainty avoidance. This suggests that rising opportunity costs of self-employment play a less important role in this cultural environment, or are being compensated by increasing entrepreneurial opportunities.
\end{abstract}

CITATION: Please cite this paper as: S. Wennekers, R. Thurik, A. van Stel and N. Noorderhaven (2007), 'Uncertainty Avoidance and the Rate of Business Ownership across 21 OECD Countries, 1976-2004', Journal of Evolutionary Economics 17 (2), 133-160.

JEL-CODES: P52, Z1, M13, O11, O57.

KEYWORDS: business ownership, uncertainty avoidance, cross country study, comparative analysis of economies, cultural economics, entrepreneurship

ACKNOWLEDGEMENT: An early version of the present paper was read at the Workshop on Entrepreneurship and Culture, held at the Max Planck Institute of Economics in Jena on 7 February 2005. The authors would like to thank Geert Hofstede, Lorraine Uhlaner and two anonymous referees for helpful comments. The paper has been written in the framework of the research program SCALES which is carried out by EIM and is financed by the Dutch Ministry of Economic Affairs. 


\section{UNCERTAINTY AVOIDANCE AND THE RATE OF BUSINESS OWNERSHIP ACROSS 21 OECD COUNTRIES, 1976-2004}

\section{INTRODUCTION}

The prevalence of business ownership, expressed as the percentage of owner/managers of incorporated and unincorporated businesses within the labor force, differs strongly between countries. Even within the relatively homogeneous subset of the world's economically most developed nations (the OECD member countries), the diversity is considerable. In Greece, approximately one in five in the labor force is a (non-agricultural) business owner, whereas in Finland approximately one in fourteen operates a business of his own (average rates 1972-2004) (see e.g. van Stel, 2005; Thurik and Wennekers, 2004). A well-known approach explains this disparity by differences in prosperity (Kuznets, 1971). The richer the country, the fewer business owners there are. However, the first cracks in this negative relationship appeared in the late seventies (Blau, 1987 and Acs, Carlson and Karlsson, 1999). In fact, the negative relationship between prosperity and business ownership now seems to be breaking down in several (but not all) of the most prosperous countries, as they have shown a resurgence of business ownership rates in the past decades (see Carree, van Stel, Thurik and Wennekers, 2002, and van Stel and Carree, 2004, for an analysis of the relationship between economic development and business ownership, and Carree and Thurik, 2003, for a literature survey). Moreover, the dominance of economic variables explaining business ownership rates has been questioned, and other explanatory factors, such as culture, have been brought forward (Hofstede et al., 2004).

Slowly, data material has become available showing that business ownership rates follow some Ushaped path when related to the level of economic development (Thurik and Wennekers, 2004). The switch between the downward phase of this U-shape and the upward one has to do with the changing role of entrepreneurial activities. The role of entrepreneurship has changed dramatically, fundamentally shifting between what Audretsch and Thurik (2001) introduced as the model of the managed economy and that of the entrepreneurial economy. In particular, Audretsch and Thurik (2001) argue that the model of the managed economy is the political, social and economic response to an economy dictated by the forces of large-scale production, reflecting the predominance of the production factors of capital and (unskilled) labor as the sources of competitive advantage (see also Audretsch and Thurik , 2004). By contrast, the model of the entrepreneurial economy is the political, social and economic response to an economy dictated not just by the dominance of the production factor of knowledge - which can be identified as replacing the more traditional factors as the source of competitive advantage - but also by a very different, but complementary, factor: entrepreneurship capital, or the capacity to engage in and generate entrepreneurial activity. By and large, countries first move from a predominantly rural economy with a high level of business ownership to an industrial one where scale economies dominate, and then again to a service economy where small scale entrepreneurial activities are essential in many industries (see Wennekers, van Stel, Thurik and Reynolds, 2005, for an example of the U-shape using data material of the Global Entrepreneurship Monitor).

Differences in the business ownership rate between countries seem to be persistent despite the Ushaped path that appears driven by the level of economic development. There is a general intuition that cultural rather than economic variables play a role in explaining these differences, since cultural aspects are relatively time invariant (Noorderhaven, Thurik, Wennekers and van Stel, 2004). The present paper investigates the role of uncertainty avoidance. Elsewhere the role of variables such as post-materialism and dissatisfaction is studied (Uhlaner and Thurik, 2007 and Noorderhaven et al., 2004).

At the individual level, the decision to become a business owner can be viewed as the outcome of a process of occupational choice. This approach views agents as utility maximizers making an occupational choice decision - to become employee or business owner - on the grounds of the utility associated with the expected returns from the two activity types. ${ }^{1}$ Personal characteristics ${ }^{2}$ as well as cultural, institutional and

\footnotetext{
${ }^{1}$ This approach is rooted in the work of Knight (1921) and starts from the functions of the provision of entrepreneurial ability and the bearing of risks. The second function underlines the importance of risk attitudes in the occupational choice process. See, for instance, Kihlstrom and Laffont (1979) and Parker (1997), where the degree of risk aversion and the differences in risk of becoming a business owner vis-à-vis an employee are given the central role in the determination of the occupational choice. See also Freytag and Thurik (2007).
} 
economic conditions will influence these individual choices. An aggregation of these occupational choices at the level of countries shows the cumulative and interactive influence of the different determinants (Verheul, Wennekers, Audretsch and Thurik, 2002). In the present paper, we will focus on a specific cultural determinant of business ownership, viz., uncertainty avoidance, which to date has received only scant attention.

Our first research question considers the concepts of uncertainty and risk and the relevance of cultural attitudes towards uncertainty for the occupational choice with respect to business ownership. What effects of uncertainty avoidance on the choice for business ownership can be assumed to exist at the individual level, and how does this influence work at the country level? Our second question pertains to the direct influence of uncertainty avoidance on the prevalence of business ownership at the country level. Are differences in business ownership rates at the country level related to differences in uncertainty avoidance? Our third question deals with an indirect role of uncertainty avoidance through an influence on the relationship between GDP per capita and business ownership. Do differences in uncertainty avoidance alter the trade-offs between the opportunity costs and benefits of entrepreneurship in relationship to the level of economic development, and hence indirectly affect business ownership rates?

\section{UNCERTAINTY, RISK AND ENTREPRENEURSHIP}

\section{Some classical and neoclassical views}

Since the publication in 1921 of Knight's dissertation Risk, Uncertainty and Profit, it has become common usage in the social sciences to distinguish between risk and (true) uncertainty (van Praag, 1999: 322). Uncertainty is a basic fact of life. We speak of uncertainty when 'anything might happen'. Relevant examples in the economic domain are new inventions and changing consumer preferences. Basically, these are unique events. Hence there is no statistical basis for calculating a probability. Risk is a special case of uncertainty. It relates to 'disagreeable' events for which past instances may be assembled and analyzed, such as fire-damage or the insolvency of debtors. According to the Oxford Concise Dictionary, tenth edition, 1999 , risk is "the possibility that something unpleasant will happen". Risk is often expressed in a percentage or probability and, accordingly, is to some extent insurable.

According to Knight, the entrepreneur's main function is bearing the real uncertainty by making judgmental decisions in the face of incalculable and uninsurable business hazards (van Praag, 1999: 322323). ${ }^{3}$ Knight's writings present an elaboration and generalization of Cantillon's views on entrepreneurship that were originally published in 1755 and in which the main entrepreneurial function is arbitrage between supply and demand. "As Cantillon describes it, entrepreneurs buy at a certain price to sell again at an uncertain price, with the difference being their profit or loss" (Hébert and Link, 1989: 42). Most (neo)classical authors, including Say and Marshall, view entrepreneurs as being responsible for risk-bearing (van Praag, 1999: 327). Later authors on entrepreneurship, particularly those in the (neo)-Austrian tradition (such as Kirzner), emphasize the entrepreneurial quality of perception of opportunities in the face of uncertainty.

By contrast, Schumpeter (1934) in his well-known Theory of Economic Development (reprinted in Swedberg, 2000: 58) emphasizes the innovative function of the entrepreneur, the person who introduces 'new combinations' of productive means. Schumpeter's view "disposes of the conception of the entrepreneur as risk bearer". In a footnote, Schumpeter continues: "Risk obviously always falls on the owner of the means of production, ...., hence never on the entrepreneur as such". Finally, T.W. Schultz (1975) defines "entrepreneurship as the ability to deal with disequilibria, rather than the ability to deal with uncertainty" (Hébert and Link, 1989: 46). For Schultz, the bearing of risk is involved in entrepreneurship but it is "not a unique attribute of entrepreneurs".

In neoclassical economics, the role of entrepreneurship is limited to the entry that follows profit opportunities (Carree and Thurik, 1995). Neoclassical economics suggests that there are a set of possible

\footnotetext{
${ }^{2}$ See Blanchflower and Meyer (1994), Blanchflower and Oswald (1998), Douglas and Shepherd (2002), Evans and Leighton (1989, 1990), Grilo and Irigoyen (2006), Grilo and Thurik (2005a and 2005b) and Lin et al. (2000) for empirical work.

${ }^{3}$ There is no generally accepted definition of entrepreneurship. See Wennekers and Thurik (1999) for an overview. In the present paper, we adopt a pragmatic approach by equating entrepreneurship, business ownership and self-employment, and an entrepreneur will simply be understood to be the owner/manager of either an unincorporated or an incorporated business. See also Thurik and Wennekers (2004) and Davidsson (2004).
} 
outcomes and a set of probabilities that each of these outcomes will actually occur (Varian, 1992). Then, a distinction is made between risk and uncertainty. The distribution of probabilities says something about the amount of risk. If the probabilities are not known, the term 'true uncertainty' is used. In neoclassical economics, usually, the probabilities are assumed to be known. With regard to entrepreneurship and entry, the profit opportunities are supposed to be known and accessible to everybody. Therefore, pure uncertainty is commonly disregarded (Choi, 1993 and Wubben, 1993).

Economists such as Knight and Keynes and economic schools such as the Austrians and the PostKeynesians have given uncertainty more emphasis (Wubben, 1993). They define uncertainty in similar terms, but state that "especially entrepreneurs do not know the full range of outcomes nor their possibilities of occurring" (Lachmann, in Wubben, 1993).

\section{Contemporary views on risk-attitudes of entrepreneurs}

The topic of risk (i.e. chance of failure) has remained current in more recent academic literature on entrepreneurship. Kihlstrom and Laffont (1979) emphasize that individuals differ in 'risk aversion'. In their model, "more risk averse individuals become workers while the less risk averse become entrepreneurs". Likewise, Iyigun and Owen (1998) model the occupational choice between 'inherently risky entrepreneurial ventures' and relatively 'safe' alternatives such as professional activities.

McGrath, MacMillan and Scheinberg (1992) compare values, including attitudes towards risk and failure, of entrepreneurs (founder-managers of stand-alone businesses that were at least two years old and employed at least one other person) and non-entrepreneurs in eight nations. Entrepreneurs were found to agree more often with statements such as 'start-up means risk but also excitement', whereas nonentrepreneurs agreed more to 'failure means losing face/respect'. Van Praag (1996) investigates which abilities and attitudes predispose individuals to entrepreneurship. In a sample of 1,763 economically active (Dutch) adults in their early fifties in 1993, more risk averse individuals were found to have a significantly smaller probability of being a business owner or having been one in the past.

Uncertainty is particularly relevant for start-up entrepreneurs because they cannot know the full range of possible outcomes (Bhide, 1994). New business founders thus are often unable to calculate their future profits. For example, someone who plans a new outlet of an existing franchise chain might have a fair estimate of its success given the experiences with previous outlets. For founders of new businesses, or more generally for entrepreneurs who introduce an innovation, this does not hold.

\section{Synthesis of micro-economic views}

Uncertainty is a concept that is central to entrepreneurship, as emphasized by eminent economists such as Cantillon, Mangoldt, Knight and Keynes (Hébert and Link, 1989; Ekelund and Hébert, 1990). Without uncertainty, entrepreneurship would be unnecessary. In the East European socialist planning economies, entrepreneurship was unnecessary and sometimes considered as criminal because a system of complete planning was assumed to result in optimal resource allocation. However, since uncertainty is a fact of economic life, entrepreneurs are needed to arbitrage, to take risks and to innovate (van Praag, 1996 and Wennekers and Thurik, 1999). Entrepreneurs are considered to be the primary agents dealing with uncertainty in the economy. Entrepreneurs are called for in the fast changing economic reality of today's society (Audretsch and Thurik, 2000 and 2001). Hébert and Link (1989: 47) attempt to synthesize the many diverging views. Their 'synthetic' definition of entrepreneurship incorporates (dealing with) uncertainty, risk, perception of profit opportunities, innovation and change.

Uncertainty is a wider concept, encompassing risks and opportunities as well as distinguishing between degrees of uncertainty. These dimensions are elaborated in table 1. Across the rows of the table there is a dichotomy distinguishing between possible unpleasant outcomes ('risks') and possibilities of business success ('opportunities'). Next, the columns represent different degrees of uncertainty. Column (1) describes the relatively low uncertainty when the possible outcomes and their probabilities are known. A case in point is selling fire insurance or starting a new outlet of an existing franchise. Column (2) refers to medium-high uncertainty in the sense that there is only a notion of possible outcomes and probabilities, such as may be the case with many new business start-ups. Business founders may not be able to calculate risks and expected profits, but they will often have a perception of the risks, opportunity costs and profit 
opportunities of their venture. Column (3) describes the 'true' uncertainty of future loss or profit, inherent to launching a radical innovation or to investing financial capital in fundamental research.

\section{INSERT TABLE 1}

There is agreement that entrepreneurs (in the sense of business owners) make judgmental decisions in the face of uncertainty, reap the rewards of perceiving and utilizing opportunities and in the process also run the risk of losing their money and their reputation. There is also some consensus that entrepreneurs are less averse to risk, while alternative views hold that entrepreneurs are inherently more optimistic rather than less risk averse or dispose of relevant information reducing uncertainty and risk (Gifford, 2003: 37-41).

\section{Cultural traits with respect to uncertainty}

Attitudes, such as risk aversion, pertain to individuals and may show a wide variety within groups. At the 'ecological level' of nations, cultural traits related to these individual attitudes may be distinguished. Empirically, these traits may be derived as mean, modal or extreme values of individual observations or through a direct analysis of 'ecological data' (pertaining to national practices and achievements). Cultural traits represent a nation's 'mental programs' that are developed in socialization processes in the family in early childhood and reinforced in schools and organizations (Hofstede, 2001: xix). Accordingly, cultural traits may differ between societies.

A cultural trait that is strongly associated with individual attitudes towards risk and uncertainty is 'uncertainty avoidance'. According to Hofstede (2001: 146), uncertainty avoidance has to do with the extent to which societies tolerate ambiguity. A culture is characterized by high uncertainty avoidance when its members feel threatened by uncertain or unknown situations. People in these cultures "look for structure in their organizations, institutions and relationships, which makes events clearly interpretable and predictable" (Hofstede, 2001: 148.) In countries with lower uncertainty avoidance, "not only familiar but also unfamiliar risks are accepted, such as changing jobs and starting activities for which there are no rules". Low uncertainty avoidance thus implies "willingness to enter into unknown ventures" (Hofstede, 2001: 164). Hofstede operationalizes uncertainty avoidance using three survey questions about whether employees feel "company rules should not be broken even when the employee thinks it is in the company's best interests", about their personal expected job stability and about how often they feel nervous or tense at work.

\section{Relevance of uncertainty avoidance for explaining the business ownership rate}

\section{Direct effect of uncertainty avoidance}

A micro-economic model of occupational choice is introduced to clarify the ways in which uncertainty avoidance may have an impact on the prevalence of business ownership at the country level. In this model, the individual choice between self-employment and wage-employment depends on a personal assessment and utility valuation of the expected material and immaterial rewards of these occupational alternatives, while taking the perceived risks into account (see Wennekers, 2006). For simplicity, we operationalize material rewards as the expected personal income generated by self-employment $\left(\mathrm{E}(\mathrm{I})_{\mathrm{SE}}\right)$, compared with the wage one expects to earn in a job $\left(\mathrm{E}(\mathrm{I})_{\mathrm{WE}}\right)$. We reduce the immaterial rewards of selfemployment to a gain in autonomy compared with the degree of independence that an individual will experience when working as an employee.

Below, we summarize the model in a schematic manner:

$$
\begin{aligned}
& O C_{S E, i}^{*}=\alpha_{i} U_{M R, i}+\left(1-\alpha_{i}\right) U_{I R, i} ; \quad 0<\alpha_{i}<1 \\
& U_{M R, i}=\beta_{i}\left(\left(1-\rho_{S E, i}\right) E(I)_{S E, i}-E(I)_{W E, i}\right) ; \quad \beta_{i}>0 ; \quad 0<\rho_{S E, i}<1
\end{aligned}
$$




$$
U_{I R, i}=\gamma_{i} \Delta A U T_{i} ; \quad \gamma_{i}>0
$$

Where

$O C^{*}{ }_{S E, i}=$ latent variable measuring total utility of choice for self-employment (individual i)

$U_{M R, i}=$ utility of expected change in material rewards due to self-employment

$U_{I R, i} \quad=$ utility of expected gain in immaterial rewards due to self-employment

$E(I)_{S E, i}=$ expected income self-employment

$E(I)_{W E, i}=$ expected income wage-employment

$\triangle A U T_{i}=$ gain in autonomy (self-employment versus wage-employment)

$\alpha_{i} \quad=$ parameter reflecting the relative weight in utility of material vs immaterial rewards

$\beta_{i} \quad=$ parameter transforming expected change in material rewards into utility

$\gamma_{i} \quad=$ parameter transforming expected gain in immaterial rewards into utility

$\rho_{S E, i} \quad=$ discount parameter for perceived risks of self-employment

For empirical application, an observable occupational choice variable $O C_{S E, i}$ might be added, where $O C_{S E, i}=1$ (i is self-employed) when $O C^{*}{ }_{S E, i}>0$ and $O C_{S E, i}=0$ (i is an employee) when $O C^{*}{ }_{S E, i}<0$. Parker (2004: 24-26) elaborates how this micro-economic model might be estimated after transformation into a probit or logit model. This is, however, not necessary for our purpose, i.e. the underpinning of a macroeconomic regression model.

We assume that all parameters and variables in the model are idiosyncratic with respect to individuals, i.e. we assume that, for each individual, parameters and variable values are randomly drawn from probability distributions. In addition, we assume that attitudes towards uncertainty and risk play a role in the assessments and utility valuations of the expected material and immaterial rewards. In particular, we assume that the distributions of $\rho_{S E, i}, \gamma_{\mathrm{i}}$, and $E(I)_{S E, i}$ are systematically influenced by the individual level of uncertainty aversion. That is, ceteris paribus, the distributions of these three parameters and variables are located more to the right or to the left, depending on the individual level of uncertainty aversion. This will be illustrated below. For simplicity let us assume that there are two groups of individuals, a group with a high uncertainty aversion level, $\mathrm{H}$, and a group with a low uncertainty aversion level, L. First, it is assumed that an aversion of uncertainty causes people to perceive fewer profit opportunities and to see more risks in entrepreneurship. This causes a downward bias in their assessments of the expected income of selfemployment, i.e. $\overline{\mathrm{E}(\mathrm{I})}_{\mathrm{SE}, \mathrm{H}}<\overline{\mathrm{E}(\mathrm{I})}_{\mathrm{SE}, \mathrm{L}}$, where the overscore denotes the median value of the distribution. Second, they will also attach a lower utility to a certain expected income when they feel that higher risks are involved, i.e. $\bar{\rho}_{\mathrm{SE}, \mathrm{H}}>\bar{\rho}_{\mathrm{SE}, \mathrm{L}}$. Third, it may be assumed that uncertainty averse individuals have a relatively low valuation of autonomy, i.e. $\bar{\gamma}_{\mathrm{H}}<\bar{\gamma}_{\mathrm{L}}$.

This model of individual occupational choice presents several bridges to the effects of uncertainty avoidance for the macro-economic business ownership rate. First, a culture of high uncertainty avoidance may imply a higher percentage of uncertainty/risk averse individuals within the population. ${ }^{4}$ Applying our micro-economic model at the macro level, this implies lower assessments of the expected entrepreneurial income and a higher discount for perceived risks. On the other hand, countries with low uncertainty avoidance will count more individuals with entrepreneurial values who attach a higher utility to the rewards of self-employment. These countries thus have a relatively large supply of potential entrepreneurs (see Shane, 1993, for indirect support of this assumption). In terms of our model, this means that there will be more people for whom the utility of the material rewards of self-employment $\left(U_{M R}\right)$ is positive (negative) in

\footnotetext{
${ }^{4}$ In terms of our illustration above, the group of individuals with a high uncertainty aversion level, $\mathrm{H}$, is larger than in a culture with low uncertainty avoidance.
} 
countries with low (high) uncertainty avoidance. ${ }^{5}$ This gives rise to the hypothesis that the prevalence of self-employment is diminished by high uncertainty avoidance (UAI+), while it is stimulated by low uncertainty avoidance (UAI-). In our section on Method, two clusters of countries will be defined.

However, there may also be an opposite effect because a culture of high uncertainty avoidance at the country level may be expected to imply a restrictive climate within existing firms and organizations. This would offer a relatively large gain in autonomy ( $\triangle A U T)$ to individuals choosing self-employment. Even when there are fewer enterprising individuals in such an economy, UAI+ may push many of them towards self-employment. In terms of our model, this means that, on average, the utility of the immaterial rewards of self-employment $\left(U_{I R}\right)$ will be higher in countries with high uncertainty avoidance. This leads to the hypothesis that high uncertainty avoidance (UAI+) may stimulate self-employment (see Baum et al., 1993, for an analogous reasoning with respect to the effect of low individualism at the country level).

Summarizing, there are two contradicting hypotheses with respect to the direct influence of uncertainty avoidance on the supply of business owners. On average, an UAI+ culture will result in more individuals with a relatively low value of $U_{M R}$, but it will also result in more individuals with a relatively high value of $U_{I R}$. The overall impact of these opposite forces (i.e. the net-effect on the business ownership rate) is a subject for empirical research.

\section{Indirect effect of uncertainty avoidance}

Uncertainty avoidance may also have an indirect influence on the rate of business ownership, i.e. the level of uncertainty avoidance in a nation may influence the manner in which other variables determine business ownership. For example, the degree to which increasing per capita income leads to a perception of increasing opportunity costs of entrepreneurship (compared with well-paid, safe jobs) versus a perception of increasing entrepreneurial opportunities (more niches; need for autonomy) may well be dependent on the level of uncertainty avoidance. Likewise, high unemployment levels may be interpreted as a decrease of the opportunity costs associated with business ownership, and hence stimulate entrepreneurship, but also with increased likelihood of failure, and therefore negatively related with business ownership levels, depending on the degree of uncertainty avoidance.

\section{MODELLING THE BUSINESS OWNERSHIP RATE}

The dependent variable in this study is the rate of business ownership in a nation at a certain moment in time. Our major interest is the direct and the indirect contribution of uncertainty avoidance to the variance in business ownership across nations and over time. We position our study within a broad multidisciplinary framework that is based on various strands of the entrepreneurship literature (see Verheul et al., 2002, and Wennekers, 2006, for a description of this framework). From this framework, we choose control variables for our regression model of the effects of uncertainty avoidance. Table 2 lists economic and demographic determinants of business ownership. Here, we not only focus on the underlying microeconomic studies of occupational choice, but also refer to surveys and empirical macro-economic investigations. The first column also contains an operationalization of the determinants used in the empirical analysis, while the final column indicates the data availability and the sources of the various variables. As we will use data for business ownership (the dependent variable in our study) for the years 1976, 1990 and 2004, and we will use a four year lag for the independent variables, we have aimed at collecting data for the years 1972, 1986 and 2000 for the variables in table 2. However, when data are not available for one of these years, we use data for the closest available year. This is also indicated in the final column of table 2.

INSERT TABLE 2

\footnotetext{
${ }^{5}$ Note again that $\mathrm{OC}_{\mathrm{SE}, \mathrm{i}}^{*}$ in Equation (1) has to be positive in order for an individual to choose for self-employment, as the utility variables in the model are defined relative to the situation of wage-employment.
} 


\section{Level of economic development}

It has been observed in various studies that the business ownership rate decreases as economies become more developed (Schultz, 1990; Yamada, 1996; see Carree et al., 2002, for an overview). Economic development is usually measured by per capita income, but it is also reflected in the average wage rate. In the present discussion, we will include both per capita income and the wage rate.

A low level of prosperity usually coincides with a low wage level, implying little pressure to increase efficiency or the average scale of enterprise. Small firms in agriculture, crafts and retail trade are therefore dominant in such an economy. A major route for ambitious wage earners to increase their income, then, is to set up shop and become an entrepreneur.

Subsequently, economic development leads to a rise in wages, which stimulates enterprises to work more efficiently and to reap economies of scale and scope (Chandler, 1990). Also, a declining share of agriculture and an increasing share of manufacturing diminish the opportunities for self-employment. At the supply side of the labor market, an additional effect of rising wage levels is an increased attraction of wageemployment, increasing the opportunity cost of self-employment (Lucas, 1978). Iyigun and Owen (1998) argue that with economic development the "safe" professional earnings will rise and fewer individuals will be willing to risk becoming business owners.

In recent decades, statistical evidence points at a possible reversal of the negative relationship between real per capita income and self-employment at an advanced level of economic development. With rising per capita income, a differentiation of consumer demand for both goods and services creates new market niches and provides opportunities for business ownership. At the supply side of entrepreneurship, social psychology hypothesizes a hierarchy of human motivations, ranging from material needs to selfrealization (Maslow 1970). By providing autonomy, entrepreneurship may become a more attractive occupational choice at higher levels of income.

However, this reversal is not universal, as witnessed by the continued decline of business ownership in some highly developed economies such as France and Japan (Verheul et al., 2002). Two opposing forces may be at play here: while rising wage levels will continue to increase the opportunity costs of selfemployment, differentiation of consumer wants will create more opportunities for new enterprises. Occupational choices in countries with low uncertainty avoidance may be influenced more strongly by the latter effect than by the first. In high uncertainty avoidance countries, it may be the other way around. Consequently, at advanced levels of economic development, we conjecture a differential impact of increasing prosperity in low (UAI-) and in high (UAI+) uncertainty avoidance countries. In UAI+ countries, the negative relationship between the level of prosperity and the self-employment rate will be undiminished across economic development. In UAI- countries, the negative relationship between prosperity and the selfemployment rate will be weaker or even reverse after a certain turning point.

\section{Share of services}

At the high end of economic development, the share of the services sector usually increases relative to that of manufacturing. On average, self-employment rates in services are considerably higher than in manufacturing (see van Stel and Carree, 2004). It requires only relatively modest investments to set up an enterprise in many services. We assume that an increasing share of the services sector will increase the business ownership rate.

So far, empirical research on this compositional effect on the business ownership rate is scant. Wennekers and Folkeringa's (2002) investigation of long-term trends in the business ownership rate of the Netherlands showed that sector shifts clearly played a part, but within-sector trends turned out to be even more important. For an analogous conclusion about trends in the firm size distribution of six large OECD countries, see Loveman and Sengenberger (1991).

\section{Relative earnings of self-employment}

In a previous section of the present paper we discussed a model of individual occupational choice. This model assumes that relative earnings of self-employment versus wage-employment affect occupational 
choice. Ceteris paribus, the better the prospects of entrepreneurial income as compared to the wage income of employees, the more people will be attracted to self-employment. ${ }^{6}$

Parker (2004: 68-70) presents a survey of the empirical evidence for this relationship. Various investigations using a structural probit model, including relative earnings as determinants of individual occupational choice, give mixed results. Two time-series studies at a more aggregate level, also cited by Parker, find a significant contribution of aggregate earnings differentials to explaining trends in the UK selfemployment rate.

In our empirical analysis, we use the macro-economic labor income share as a (reverse) proxy for the (expected) entrepreneurial income relative to the wage income. The labor income share is defined as the sum of wages including 'imputed wage income of self-employed persons', expressed as a fraction of total income. This is admittedly a rough proxy.

The relationship between relative earnings and the business ownership rate may be moderated by the degree of uncertainty avoidance. In an occupational choice perspective, the weighing of expected entrepreneurial and wage income against one another also includes an assessment of the risks involved. In UAI- countries, the entrepreneurial risks will be viewed more lightly and accordingly the effect of relative earnings may be stronger than in UAI+ countries.

\section{Unemployment}

(The threat of) unemployment is a factor diminishing the opportunity costs of self-employment, particularly when unemployment benefits are low relative to (minimum or average) wages. However, when structural unemployment is very high, this may indicate bleak business opportunities and discourage business ownership (Hamilton, 1989 and Meager, 1992). Exactly where the negative influence of rising unemployment begins to outbalance the positive effect of decreasing opportunity costs depends on a perception of uncertain future events, and may therefore be related to the level of uncertainty avoidance in a country. Hence we expect the positive effects of unemployment to dominate in UAI- countries, and the negative effects in UAI+ countries.

\section{Social security entitlements}

High social security entitlements for employees contribute to the opportunity costs of entrepreneurship, and may be expected to have a negative influence on the business ownership rate. This has been confirmed in several empirical investigations (Ilmakunnas, Kanniainen and Lammi, 1999; Parker and Robson, 2004; Hessels, van Stel, Brouwer and Wennekers, 2006) reporting negative effects on selfemployment of employers' social security contributions and/or the unemployment benefit replacement rate.

\section{Income disparity}

Some scholars hypothesize that an equal income distribution may limit the required asset accumulation facilitating enterprise formation, while income disparity may be favorable to entrepreneurship (Ilmakunnas et al., 1999). At the lower end of the income distribution, inequality may act as a push factor to enter self-employment. Additionally, on the demand side of entrepreneurship, income disparity is likely to create a more differentiated demand for goods and services. Empirical research by Ilmakunnas et al. suggests that income inequality positively influences the rate of self-employment, although reversed causality cannot be ruled out.

\section{Financial variables}

Starting and running a business requires financial capital. This capital is needed to purchase or rent the premises, to invest in equipment and/or vehicles, to purchase raw materials, to finance market research and advertising and to advance wages. The need for financial capital differs strongly with the line of business. Financial resources for business start-ups are often derived from self-financing (including savings, gifts, inheritances and lottery wins). Additionally, informal investors, mortgage loans, commercial credit and

\footnotetext{
${ }^{6}$ In a micro-economic model of occupational choice (de Wit, 1993), equality of entrepreneurial income and wages determine the equilibrium number of self-employed. In this model, an exogenous wage increase lowers the (equilibrium) number of self-employed while an exogenous upward shift of profits raises the equilibrium.
} 
bank loans and (very rarely) venture capital can also be a source of start-up capital (Bygrave and Hunt, 2005).

Capital constraints, often related to lack of assets or collateral, may create serious impediments for business start-ups (Blanchflower and Oswald, 1998; Evans and Leighton, 1989; van Praag, 1996) and for young and growing firms (Chittenden, Hall and Hutchinson, 1996; LeCornu and McMahon, 1996). An influential paper by Evans and Jovanovic (1989) has stimulated research on credit rationing. For a survey of this literature, see Parker (2004). While a clear conclusion on the prevalence of credit rationing seems yet out of reach, there is ample evidence that self-employment rates are positively related to personal wealth (real estate and other assets).

Finally, the direct and indirect (opportunity) costs of financing a business depend on the rate of interest. Higher interest rates may be expected to have a negative effect on business ownership. Parker (2004: 104, 105) weighs the empirical evidence. In particular, several UK and US time-series studies show a significant negative effect of the interest rate on the self-employment rate.

\section{Demographic characteristics}

With respect to gender, in most surveys women are found to be less likely to be involved in either self-employment or early-stage entrepreneurial activity than are men, although the difference varies across nations (Minniti, Arenius and Langowitz, 2005; Verheul, 2005). Econometric analysis of a large Swedish dataset of individual business start-ups has shown a remaining 'pure' gender effect after correcting for other differences, such as education and previous management experience (Delmar and Davidsson, 2000). A higher labor participation rate of women thus in itself means a lower overall business ownership rate in the labor force.

The role of population density at the national level is less obvious. Every local area needs a minimum supply of facilities in retail trade, repair and personal services. Therefore, thinly populated regions will have relatively many small retail outlets, workshops and service providers. Conversely, urban areas will give rise to economies of scale through which small-sized entrepreneurship in particularly retailing comes under pressure (Bais, van der Hoeven and Verhoeven, 1995). On the other hand, networks and other supply side factors in urban areas are conducive to new entrepreneurship in many service industries (Audretsch and Keilbach, 2004).

Education is somewhat of an anomaly. Research conducted on a Swedish sample at individual level, showing that nascent entrepreneurs attained on average a higher educational level ${ }^{7}$ than those in a control sample (Delmar and Davidsson, 2000), has been reconfirmed in recent investigations across several highincome countries (Acs, Arenius, Hay and Minniti, 2004). On the other hand, macroeconomic research with respect to a static index of entrepreneurship suggests the opposite conclusion. For instance, Uhlaner, Thurik and Hutjes (2002) found that countries with a higher level of education tend to have a smaller proportion of self-employment. In a recent comparative study across 27 OECD countries, countries with a higher level of enrollment in secondary education show a lower level of early-stage entrepreneurship, while higher enrollment in tertiary education was found to have a positive effect on both early-stage entrepreneurship and total business ownership (Uhlaner and Thurik, 2007).

With respect to the age composition of the population, Blanchflower, Oswald and Stutzer (2001: 686) report that, while 'older people are more likely to be self-employed, it is younger people who say they would prefer to be self-employed'. Earlier research also shows that people in the middle age cohorts have the highest prevalence of incumbent business owners (Storey, 1994). In many countries, prevalence rates of nascent entrepreneurship are highest in the age group between 25 and 34, while, according to some research, a tendency towards start-ups at a younger age is also apparent. ${ }^{8}$ Ceteris paribus, the ageing of the population in most developed countries implies a threat to the future development of business ownership.

\section{METHOD AND DATA}

\footnotetext{
${ }^{7}$ In addition, nascent entrepreneurs were found to have more management experience.

${ }^{8}$ Delmar and Davidsson (2000), EIM/EZ (2000), van Gelderen (1999:21) and various annual Executive Reports published by the Global Entrepreneurship Monitor.
} 


\section{Method}

First, we investigate the direct influence of uncertainty avoidance on the business ownership rate by means of a regression analysis of pooled panel data for 21 countries in 1976, 1990 and 2004, given the influence of (four years lagged) per capita income and some other control variables (also four years lagged). The control variables are chosen from table 2 on the basis of data-availability. We assume that the samples for 1976, 1990 and 2004 are sufficiently independent to warrant pooling them in one regression. Because uncertainty avoidance was measured only once (around 1970), its role in the pooled regression analysis may be interpreted as that of a country-specific time-invariant variable. Next, we use the years 1976, 1990 and 2004 as separate samples to investigate the stability of the direct relationship over time.

Second, we explore the possible indirect influence of uncertainty avoidance on the rate of business ownership. This means that we have added an interaction term between per capita income and uncertainty avoidance to the multiple regression analysis of the pooled sample for 1976, 1990 and 2004. Finally, we repeat this regression, substituting UAI by a dummy variable representing two separate clusters of countries. In our dataset, the following thirteen countries form the cluster ${ }^{9}$ of low uncertainty avoidance: Denmark, Finland, Germany, Ireland, the Netherlands, Sweden, Great Britain, Norway, Switzerland, USA, Canada, Australia and New Zealand. Another eight countries, i.e. Austria, Belgium, France, Italy, Greece, Portugal, Spain and Japan, make up the cluster with high uncertainty avoidance. By comparing these two models we hope to find indications whether the effects of uncertainty avoidance are discrete or continuous (see also Cohen and Cohen, 1983).

\section{Data}

Harmonized non-agricultural business ownership rates for 23 OECD-countries are available from EIM's COMPENDIA data base. ${ }^{10}$ These data include the owners of incorporated and unincorporated businesses but exclude unpaid family workers. The countries in COMPENDIA include 18 European countries as well as the USA, Japan, Canada, Australia and New Zealand. Data are available for the even years from 1972 onwards.

Additionally, Hofstede (2001) provides data on uncertainty avoidance for 21 of the 23 countries mentioned above. ${ }^{11}$ Uncertainty avoidance is a key variable in Hofstede's well-known study ${ }^{12}$ of cultural dimensions across some 50 different nations and regions. The uncertainty avoidance index (UAI) was computed on the basis of the country mean scores for three different survey questions already mentioned in a previous section of the present paper. Because the surveys on which the index was based were held between 1967 and 1973, the stability of the index is a crucial aspect for our study into the rate of business ownership in the years 1976, 1990 and 2004. Hofstede (2001:34) claims that national cultures are extremely stable over time. He argues that '... this stability can be explained from the reinforcement of culture patterns by the institutions that themselves are products of the dominant cultural value systems'. In the long run, 'cultures shift, but they shift in formation, so that the differences between them remain intact' (Hofstede, 2001: 255). Chapters 2 and 4 of Hofstede's book present abundant statistical information about the stability and reliability of the uncertainty avoidance index. Our best assessment is that this index can be used for explaining national rates of entrepreneurship during several decades following the measurement of the index.

An alternative would have been to use the uncertainty avoidance data reported by the GLOBE project (House et al., 2004). We refrain from doing so for two reasons. First, Hofstede's uncertainty avoidance index is well understood, and has been used in many previous studies. Hofstede (2001) also reports extensively on correlates of his uncertainty avoidance index with measures from over one hundred other studies. Comparable validation of the GLOBE uncertainty avoidance scales is not available. Second, there are some conceptual difficulties with the GLOBE uncertainty avoidance scales. GLOBE constructed

\footnotetext{
${ }^{9}$ The clustering was carried out with the K-means algorithm. See Noorderhaven et al. (1999).

${ }^{10}$ COMParative ENtrepreneurship Data for International Analysis. See van Stel (2005). In the current paper, data from COMPENDIA version 2004.2 are used.

${ }^{11}$ No data on Hofstede's indices are available for Iceland, whereas for Luxembourg there are estimates that we have used for clustering only. See Noorderhaven et al. (1999).

${ }^{12}$ This study was first published in 1980, but the second edition, published in 2001, gives more information on stability and crossvalidation of the data.
} 
two scales, the actual use of uncertainty avoidance mechanism in the respondent's society ("practices"), and the desired use of uncertainty avoidance mechanisms ("values"). These two scales are negatively correlated. The GLOBE practices scale is also negatively correlated to Hofstede's UAI scale, the GLOBE values scale positively (Sully de Luque and Javidan, 2004). ${ }^{13}$ This makes the GLOBE scales difficult to interpret. The authors note that most countries with high uncertainty avoidance practices are technologically developed nations (Sully de Luque and Javidan, 2004: 621). This makes the index less relevant for the current study, as we are comparing levels of business ownership across developed countries only. Both GLOBE uncertainty avoidance scales are strongly correlated with economic prosperity, the "practices" scale positively, and the "values" scale negatively (Sully de Luque and Javidan, 2004: 631). Hofstede's UAI, in contrast, is only weakly correlated to economic prosperity (Hofstede, 2001: 201). Consequently, Hofstede's index measures cultural characteristics of countries that are relatively independent of wealth, and thus this index forms a good complement to the economic indicators we also use in this study.

For the operationalization and sources of the control variables, we refer to table 2. Besides the controls included in table 2, we also include year dummies in our analysis. Recent decades have witnessed a worldwide diffusion of new information and communication technologies, as well as a widespread tendency towards deregulation of markets. Both phenomena have created opportunities for small scale business and new entrepreneurship. Audretsch and Thurik (2000 and 2001) label this as a regime switch from 'a managed to an entrepreneurial economy'. We try to catch these developments using year dummies as controls in our analysis.

Table 3 presents the correlation matrix of the pooled sample for 1976, 1990 and 2004. The highest (positive) correlations among the control variables include those between per capita income, on the one hand, and the female labor share and tertiary education, on the other. Uncertainty avoidance and per capita income show a moderate degree of (negative) correlation in our sample.

\section{INSERT TABLE 3}

\section{RESULTS}

\section{Direct influence of uncertainty avoidance}

Table 4 presents the regressions on the pooled sample for 21 countries in 1976, 1990 and 2004. First, we regress business ownership on uncertainty avoidance, GDP per capita and the year dummy variables. This is the 'base model', shown in the first column of the table. The significantly positive coefficient for uncertainty avoidance is support for Baum's hypothesis, stating that dissatisfaction with a climate of high uncertainty avoidance in large organizations may push enterprising individuals towards selfemployment. GDP per capita and the year dummies are also significant and have the expected sign. Next, we introduce the other control variables one by one. In all but one of these regressions, the coefficient for uncertainty avoidance is significantly positive. The only exception is the regression including the Gini index, which is based on 37 observations only. With respect to the significant control variables, the only counterintuitive result is the positive sign for the long term interest rate. Subsequently, as shown in the second to last column of table 4, we regress business ownership on uncertainty avoidance while including all control variables that are significant in the previous regressions ${ }^{14}$. Finally, the last column shows the variables that are significant in a 'complete model'. These are uncertainty avoidance $(+)$, per capita income $(-)$, the share of services $(+)$, the unemployment replacement rate (-) and the dummy variables for 1990 and $2004(+)$.

\footnotetext{
${ }^{13}$ For the 19 countries in our dataset for which we have both Hofstede and GLOBE data on uncertainty avoidance, the correlations are: Hofstede UAI x GLOBE practices: -.643; Hofstede UAI x GLOBE values: .607; GLOBE practices x GLOBE values: -.869. All these correlations are significant at the $1 \%$ level.

${ }^{14}$ Excluding the Gini coefficient and the long term interest rate, due to the smaller available number of observations of these variables.
} 
Table 5 presents the regressions in three separate sample years 1976, 1990 and 2004. For each year, the left-hand column presents a regression including the control variables that were listed in the second to last column of table 4 , while the right-hand column reports significant control variables only. The main finding for the sample of 1976 is a significantly positive influence of uncertainty avoidance on the rate of business ownership. In 1990, the coefficient of uncertainty avoidance is again positive, but no longer fully significant. In 2004, no influence of UAI is found. All regressions confirm the well-known negative influence of GDP per capita.

\section{INSERT TABLE 5}

The main outcome of table 5 is that the positive effect of uncertainty avoidance fades away over time. Our interpretation is that the advent of the entrepreneurial economy in recent years, as discussed in our Introduction, has created new pull factors mobilizing the relatively abundant supply of potential entrepreneurial capital in countries with low uncertainty avoidance. So Baum's push hypothesis for high uncertainty avoidance and Shane's pull hypothesis for low uncertainty avoidance may now be equally valid, effectively countervailing one another in the regression for 2004. Another explanation could be that the measurement of uncertainty avoidance (which was carried out around 1970) has lost some of its validity 30 years onwards, but the arguments discussed in the Data section offer no specific support for this interpretation. The coefficients for GDP per capita and to a lesser extent for the share of services and the replacement rate are relatively stable over time. The two other control variables, i.e. the female labor share and the share of the age group 25-39, are only significant for 2004. These results are consistent with the findings in the last two columns of table 4.

We conclude that there is evidence for a push effect of high uncertainty avoidance on the rate of business ownership. However, in recent years, a pull towards entrepreneurship in a climate of low uncertainty avoidance may have gained dominance vis-à-vis this longstanding historical push effect of high uncertainty avoidance. We have also found consistent confirmation of the well-known observation of a negative bearing of per capita income on business ownership. Finally, most results support a positive influence of the share of services and a negative effect of the replacement rate.

\section{Indirect influence of uncertainty avoidance}

Next, we explore the possible indirect influence of uncertainty avoidance on the rate of business ownership, by adding an interaction term between per capita income and uncertainty avoidance to the pooled panel regressions. The two left-hand columns of table 6 compare the results of the base model including this interaction term in addition to uncertainty avoidance, GDP per capita and the year dummy variables with the original base model as presented in table 4 . The main outcome is a significant (at $10 \%$ level) intermediate effect of uncertainty avoidance on the influence of GDP per capita. ${ }^{15}$ What do these results mean in a quantitative sense? As an illustration, the results imply that for the country with the highest UAI-rate in the sample (Greece), an increase in real per capita income with $\$ 1.000$ would imply a decrease of the business ownership rate with 0.61 percentage points, while for the country with the lowest uncertainty avoidance rate (Denmark), this increase in income would mean a decline in business ownership with 0.14 percentage points only. These differences show that the indirect effect exists indeed.

\section{INSERT TABLE 6}

The right-hand columns of table 6 present regressions in which uncertainty avoidance has been substituted by a dummy variable representing a high and a low uncertainty avoidance cluster of countries, as

\footnotetext{
${ }^{15}$ This appears both from the significance level of the interaction term (p-value is .078) and from a loglikelihood test comparing the models in the first two columns of table 6 . The LR test statistic is 3.4 while the $10 \%$ critical value is 2.71 .
} 
explained in the section on Method and Data. The results are similar to those including the continuous scale for UAI, as discussed in the previous paragraph. Again, the model including both a direct and an indirect effect of uncertainty avoidance outperforms the model including a direct effect only (at $10 \%$ level). An increase in real per capita income with $\$ 1.000$ implies a decrease of the business ownership rate with 0.59 percentage points in the UAI+ countries and a decline with 0.28 percentage points in the UAI- countries.

Next, we test the robustness of the indirect effect by adding the share of services and the replacement rate as control variables. Table 7 reports the results. As can be seen from columns 2 and 4, the indirect effect then becomes somewhat smaller and is no longer fully significant.

\section{INSERT TABLE 7}

By and large, there are serious indications of a differential effect of per capita income on entrepreneurship across the rate of uncertainty avoidance, but the robustness of these results is limited. A final observation on the basis of tables 6 and 7 is that the statistical fit of a 'discrete effect' of uncertainty avoidance is not significantly better than that of a 'continuous effect' ${ }^{16}$

\section{CONCLUSIONS}

The prevalence of entrepreneurship, expressed as the percentage of business owners in the labor force, differs strongly between countries. The causes of this disparity do not only have an economic basis, but also stem from cultural differences between countries (Hofstede et al., 2004 and Noorderhaven et al., 1999). The persistence of the country differences throughout the economic cycles points at cultural determinants, which are relatively constant per country.

Using a pooled dataset of a large number of OECD countries in 1976, 1990 and 2004, we have found a positive direct influence of uncertainty avoidance on business ownership rates, indicating that, in those years, a climate of high uncertainty avoidance in existing firms and organizations may push enterprising individuals towards self-employment (Baum's hypothesis, as discussed before). These findings also show that a personal trait (risk aversion) and its cultural counterpart (uncertainty avoidance) may have a diverging impact on entrepreneurship. Repeating these regressions in three separate sample years confirms these results for 1976 and 1990. However, for the year 2004, the main outcome is that uncertainty avoidance no longer has any direct influence on business ownership. Our interpretation is that the advent of the entrepreneurial economy in recent years has created pull factors mobilizing the relatively abundant supply of potential entrepreneurial capital in countries with low uncertainty avoidance. In recent years, a pull towards entrepreneurship in a climate of low uncertainty avoidance has gained dominance vis-à-vis a longstanding historical push effect of high uncertainty avoidance.

We also found evidence for a negative indirect influence of uncertainty avoidance through a moderating effect on the influence of per capita income on business ownership. In low uncertainty avoidance countries, the negative influence of per capita income on the rate of business ownership is clearly smaller than in high uncertainty avoidance countries. In a group of eight high-uncertainty avoidance countries, a relatively strong negative relationship between GDP per capita and the level of business ownership suggests that rising opportunity costs of entrepreneurship are the dominant perception in this cultural environment. On the other hand, in a group of thirteen low-uncertainty avoidance countries, the relatively weak negative relationship between business ownership and per capita income suggests that rising opportunities are a countervailing force in an environment of low uncertainty avoidance.

A closer look at the underlying development of the business ownership rate in all 21 countries between 1972 and 2004 reveals the following. In the group of low-uncertainty avoidance countries, eight out of thirteen nations show either a clear U-shape (Finland, Germany, the Netherlands and New Zealand) or a vaguely U-shape trend (Australia, Great Britain, Sweden and USA), three show a continuously upward trend in entrepreneurship (Canada, Ireland and Switzerland), one shows a stabilization in the last twenty years

\footnotetext{
${ }^{16}$ Note that, in table 6 , the $\mathrm{R}^{2}$ of the continuous effect model is (slightly) higher compared to the discrete effect model while in table 7 , this is the other way around.
} 
(Denmark), while only one (Norway) shows a decreasing trend. ${ }^{17}$ In the group of high-uncertainty avoidance countries, two out of eight countries (France and Japan) ${ }^{18}$ show a strongly decreasing trend, while six show an increase or a U-shape, sometimes followed by stabilization. While the large number of countries with rising business ownership rates across both groups bear witness to a worldwide trend toward more entrepreneurship related to ICT and deregulation, the differential indirect effects of uncertainty avoidance also suggest that, in modern service economies, high uncertainty avoidance may indirectly have a negative impact on the development of business ownership and may hamper the exploitation of new economic opportunities.

Our study has some limitations that should be borne in mind when interpreting the results. First, the modest explanatory power of most of our regressions suggests that other cultural and psycho-sociological variables may also play a role ${ }^{19}$. Second, our paper only studies the effect of uncertainty avoidance on the level of entrepreneurship. It would be relevant to repeat the study for the dynamics of entrepreneurship, although a lack of time series of harmonized business start-up data across countries may hamper the latter at least in the near future. Finally, business ownership rates are available for a far smaller number of countries than uncertainty avoidance data. This inhibits fuller testing of the direct and the indirect effect of uncertainty avoidance.

Nonetheless, the present results may already have some relevance for policymakers trying to promote entrepreneurship. While we would not advocate social engineering, the results do suggest that countries should investigate to what extent their educational system and relevant labor market, social and fiscal legislation foster a low or a high degree of uncertainty avoidance within the population.

\section{REFERENCES}

Acs, Z.J., B. Carlson and Ch. Karlsson (1999), "The linkages among entrepreneurship, SMEs and the macroeconomy," In: Z.J. Acs, B. Carlson and Ch. Karlsson (eds), Entrepreneurship, Small \& MediumSized Enterprises and the Macroeconomy, Cambridge: Cambridge University Press, 3-42.

Acs, Zoltan, Pia Arenius, Michael Hay and Maria Minniti (2004), Global Entrepreneurship Monitor: 2004 Executive Report, Babson College and London Business School.

Audretsch, D.B., and M. Keilbach (2004), "Entrepreneurship Capital and Economic Performance", Regional Studies 38 (8), 949-959.

Audretsch, D.B. and A.R. Thurik (2000), "Capitalism and democracy in the 21st century: from the managed to the entrepreneurial economy," Journal of Evolutionary Economics 10 (1), 17-34.

Audretsch, D.B. and A.R. Thurik (2001), "What is new about the new economy: sources of growth in the managed and entrepreneurial economies," Industrial and Corporate Change 10 (1), 267-315.

Audretsch, D.B. and A.R. Thurik (2004), "A model of the entrepreneurial economy," International Journal of Entrepreneurship Education 2 (2), 143-166.

Bais, J., W.H.M van der Hoeven and W.H.J. Verhoeven (1995), Determinanten van zelfstandig ondernemerschap: een internationale vergelijking, Den Haag: OSA-werkdocument.

Baum, J.R., J.D. Olian, M. Erez, E.R. Schnell, K.G. Smith, H.P. Sims, J.S. Scully and K.A. Smith (1993), "Nationality and work role interactions: a cultural contrast of Israeli and U.S. entrepreneurs' versus managers' needs," Journal of Business Venturing 8, 499-512.

Bhide, A. (1994), "How entrepreneurs craft strategies that work," Harvard Business Review, March-April, 150-161.

Blanchflower, D.G. and B.D. Meyer (1994), "A longitudinal analysis of the young self-employed in Australia and the United States," Small Business Economics 6, 1-19.

Blanchflower, D.G. and A.J. Oswald (1998), "What makes an entrepreneur?" Journal of Labor Economics $16(1), 26-60$.

\footnotetext{
${ }^{17}$ However, in 2004, Norway had a significant rise in the business ownership rate compared to 2002, possibly indicating a stabilization or even reversal of the downward trend. By contrast, while Canada and Switzerland show an increasing trend over the period 1972-1998, the business ownership rates of these countries are decreasing since 1998.

${ }^{18}$ In addition, Luxemburg, that estimates show to be a high uncertainty avoidance country, also has a declining trend.

${ }^{19}$ This includes individualism (Shane, 1993), post-materialism (Uhlaner and Thurik, 2007) and dissatisfaction (Noorderhaven et al., 2004).
} 
Blanchflower, D.G., A. Oswald and A. Stutzer (2001), "Latent entrepreneurship across nations", European Economic Review 45, 680-691.

Blau, D. (1987), “A time series analysis of self-employment," Journal of Political Economy 95, 445-467.

Bygrave, W.D and S.A. Hunt (2005), Global Entrepreneurship Monitor 2004 financing report, Babson College and London Business School.

Carree, Martin, André van Stel, Roy Thurik and Sander Wennekers (2002), "Economic development and business ownership: an analysis using data of 23 OECD countries in the period 1976-1996," Small Business Economics 19 (3), 271-290.

Carree, Martin and Roy Thurik (1995), 'Profitability and number of firms: their dynamic interaction in Dutch retailing'. In: A. van Witteloostuijn (ed), Studies in Industrial Organization: Market Evolution: Competition and Cooperation, Boston/Dordrecht: Kluwer Academic Publishers, 257-266.

Carree, Martin and Roy Thurik (2003), “The impact of entrepreneurship on economic growth", In: Z.J. Acs and D.B. Audretsch (eds), Handbook of Entrepreneurship Research, Boston/Dordrecht: Kluwer Academic Publishers, 437-471.

Chandler, A.D. Jr. (1990), Scale and Scope: the Dynamics of Industrial Capitalism. Cambridge: Harvard University.

Chittenden, Francis, Graham Hall and Patrick Hutchinson (1996), "Small firm growth, access to capital markets and financial structure: review of issues and an empirical investigation", Small Business Economics 8 (1), 59-67.

Choi, Y.B. (1993), Paradigms and Conventions: Uncertainty, Decision Making and Entrepreneurship. Ann Arbor: University of Michigan Press.

Cohen, Jacob and Patricia Cohen (1983). Applied Multiple Regression/Correlation Analysis for the Behavioral Sciences. Hillsdale, NJ: Lawrence Erlbaum Associates.

Davidsson, P. (2004), Researching Entrepreneurship, International Studies in Entrepreneurship, Boston etc: Springer Science Inc.

Delmar, F. and P. Davidsson (2000), "Where do they come from? Prevalence and characteristics of nascent entrepreneurs," Entrepreneurship and Regional Development 12, 1-23.

Douglas, E.J. and D.A. Shepherd (2002), "Self-employment as a career choice: attitudes, entrepreneurial intentions, and utility maximization," Entrepreneurship Theory and Practice 26 (3), 81-90.

EIM/EZ (2000), Entrepreneurship in the Netherlands; opportunities and threats to nascent entrepreneurship, Zoetermeer: EIM.

Ekelund, R.B. and R.F. Hébert (1990), A History of Economic Theory and Method. New York: McGrawHill.

Evans, David S. and Boyan Jovanovic, 1989, "An estimated model of entrepreneurial choice under liquidity constraints," Journal of Political Economy, 97(4), 808-827.

Evans, D.S. and L.S. Leighton (1989), "Some empirical aspects of entrepreneurship," American Economic Review 79(3), 519-535.

Evans, D.S. and L.S. Leighton (1990), "Small business formation by unemployed and employed workers," Small Business Economics 2, 319-330.

Freytag, A. and A.R. Thurik (2007), "Entrepreneurship and its determinants," Journal of Evolutionary Economics, this issue.

Gelderen, M.W. van (1999), Ontluikend ondernemerschap, een studie naar mensen die bezig zijn met het opzetten van een bedrijf (nascent entrepreneurs), Strategische Verkenning, Zoetermeer: EIM.

Gifford, S. (2003), "Risk and uncertainty," In: Z.J. Acs and D.B. Audretsch (eds), Handbook of Entrepreneurship Research, Boston/Dordrecht: Kluwer Academic Publishers, 37-53.

Grilo, I. and J. Irigoyen (2006), "Entrepreneurship in the EU: to wish and not to be," Small Business Economics, forthcoming.

Grilo, I. and A.R. Thurik (2005a), Determinants of entrepreneurial engagement levels in Europe and the US, Max Planck Institute Discussion Paper on Entrepreneurship, Growth and Public Policy 25-2005, Jena, Germany: Max Planck Institute of Economics.

Grilo, I. and A.R. Thurik (2005b), "Latent and actual entrepreneurship in Europe and the US: some recent developments," International Entrepreneurship and Management Journal 1(4), 441-459.

Hamilton, R.T. (1989), "Unemployment and business formation rates: reconciling time series and crosssections," Environment and Planning A 11, 249-255. 
Hébert, R.F. and A.N. Link (1989), "In search of the meaning of entrepreneurship," Small Business Economics 1, 39-49.

Hessels, S.J.A., A.J. van Stel, P. Brouwer and A.R.M. Wennekers (2006), Social security arrangements and early-stage entrepreneurial activity; an empirical analysis, EIM Scales Paper N200518, Zoetermeer, Netherlands: EIM.

Hofstede, G. (2001), Culture's Consequences; Comparing Values, Behaviors, Institutions and Organizations Across Nations, $2^{\text {nd }}$ edition, Thousand Oaks: Sage.

Hofstede, G., N.G. Noorderhaven, A.R. Thurik, L.M. Uhlaner, A.R.M. Wennekers and R.E. Wildeman (2004), "Culture's role in entrepreneurship: self-employment out of dissatisfaction," In: J. Ulijn and T. Brown (eds) Innovation, Entrepreneurship and Culture: The Interaction between Technology, Progress and Economic Growth, Cheltenham, UK and Brookfield, US: Edward Elgar, 162-203.

House, R.J., P.J. Hanges, M. Javidan, P.W. Dorfman and V. Gupta (eds) (2004). Culture, Leadership and Organizations: The GLOBE Study of 62 Societies, Thousand Oaks: Sage.

Ilmakunnas, P., V. Kanniainen and U. Lammi, 1999, Entrepreneurship, economic risks, and risk-insurance in the welfare state, Discussion paper No. 453, Department of Economics, University of Helsinki.

Iyigun, M.F. and A.L. and Owen (1998), "Risk, entrepreneurship, and human-capital accumulation," AEA Papers and Proceedings 88(2), 454-457.

Kihlstrom, Richard and Jean-Jacques Laffont (1979), "A general equilibrium entrepreneurial theory of firm formation based on risk aversion," Journal of Political Economy 87, 719-748.

Knight, F.H. (1921), Risk, Uncertainty and Profit, New York: Houghton Mifflin.

Kuznets, Simon (1971), Economic Growth of Nations, Total Output and Production Structure. Cambridge, MA: Harvard University Press / Belknapp Press.

LeCornu, M., R. McMahon, D. Forsaith and A. Stanger (1996), "The small enterprise financial objective function", Journal of Small Business Management 34 (3), 1-14.

Lin, Z., G. Picot and J. Compton (2000), "The entry and exit dynamics of self-employment in Canada," Small Business Economics 15, 105-125.

Loveman, G. and W. Sengenberger (1991), "The re-emergence of small-scale production; an international comparison", Small Business Economics 3, 1-37.

Lucas, Robert E. Jr. (1978), "On the size distribution of business firms," Bell Journal of Economics 9, 508523.

Maslow, A.H. (1970), Motivation and Personality, New York: Harper and Row.

McGrath, R.G., I.C. MacMillan and S. Scheinberg (1992), "Elitists, risk-takers, and rugged individualists? An exploratory analysis of cultural differences between entrepreneurs and non-entrepreneurs," Journal of Business Venturing 7, 115-135.

Meager, N. (1992), "Does unemployment lead to self-employment?" Small Business Economics 4, 87-103.

Minniti, M., P. Arenius and N. Langowitz (2005), Global Entrepreneurship Monitor 2004 Report on women and entrepreneurship, Center for Women's Leadership at Babson College.

Noorderhaven, Niels, Sander Wennekers, Geert Hofstede, Roy Thurik and Ralph Wildeman (1999), Selfemployment out of dissatisfaction; an international study, Discussion paper TI 99-089/3. Tinbergen Institute, Erasmus University Rotterdam.

Noorderhaven, Niels, Roy Thurik, Sander Wennekers and André van Stel (2004), "The role of dissatisfaction and per capita income in explaining self-employment across 15 European countries", Entrepreneurship Theory and Practice 28 (5), 447-466.

Parker, S.C. (1997), "The effects of risk on self-employment," Small Business Economics 9, 515-522.

Parker, S.C. (2004), The Economics of Self-Employment and Entrepreneurship, Cambridge: Cambridge University Press.

Parker, S.C. and M.T. Robson (2004), "Explaining international variations in self-employment: evidence from a panel of OECD countries," Southern Economic Journal, 71, 287-301.

Praag, Mirjam van (1996), Determinants of Successful Entrepreneurship. Amsterdam: Thesis Publishers.

Praag, C.M. van (1999), "Some classic views on entrepreneurship," De Economist 147, 311-335.

Schultz, T.P. (1990), Women's changing participation in the labor force: a world perspective, Economic Development and Cultural Change 38, 457-488.

Schultz, T.W. (1975), "The value of the ability to deal with disequilibria", Journal of Economic Literature $13,827-846$. 
Schumpeter, J. (1934), The Theory of Economic Development, Cambridge, MA: Harvard University Press (a translation of the second edition from 1926 of a work that originally appeared in 1911).

Shane, S.A. (1993), "Cultural influences on national rates of innovation," Journal of Business Venturing 8, 59-73.

Stel, André van (2005), "COMPENDIA: harmonizing business ownership data across countries and over time", International Entrepreneurship and Management Journal 1 (1), 105-123.

Stel, André van, and Martin Carree (2004), "Business ownership and sectoral growth; an empirical analysis of 21 OECD countries", International Small Business Journal 22 (4), 389-419.

Storey, D.J. (1994), Understanding the Small Business Sector, London/New York: Routledge.

Sully de Luque, M., and M. Javidan (2004), "Uncertainty avoidance," In: R.J. House, P.J. Hanges, M. Javidan, P.W. Dorfman and V. Gupta (eds), Culture, Leadership and Organizations: The GLOBE Study of 62 Societies, Thousand Oaks: Sage: 602-653.

Swedberg, R. (2000), Entrepreneurship; The Social Science View, Oxford: Oxford University Press.

Thurik, A.R. and S. Wennekers (2004), "Entrepreneurship, small business and economic growth," Journal of Small Business and Enterprise Development 11 (1), 140-149.

Uhlaner, L.M., A.R. Thurik and J. Hutjes (2002), Post-materialism: a cultural factor influencing entrepreneurial activity across nations, Erasmus Research Institute for Management Report ERS-200262-STR, Rotterdam: Erasmus University.

Uhlaner, L.M. and A.R. Thurik (2007), "Post-materialism influencing total entrepreneurial activity across nations," Journal of Evolutionary Economics, this issue.

Varian, H.R. (1992), Microeconomic Analysis. New York: Norton.

Verheul, I. (2005), Is there a (fe)male approach? Understanding gender differences in entrepreneurship, ERIM PhD. Series Research in Management, Erasmus Research Institute of Management, Erasmus University Rotterdam.

Verheul, Ingrid, Sander Wennekers, David Audretsch and Roy Thurik (2002), "An eclectic theory of entrepreneurship: policies, institutions and culture," In: D.B. Audretsch, A.R. Thurik, I. Verheul and A.R.M. Wennekers (eds) Entrepreneurship: Determinants and Policy in a European-US Comparison, Boston/Dordrecht: Kluwer Academic Publishers, 11-81.

Wennekers, Sander (2006), Entrepreneurship at country level: economic and non-economic determinants, forthcoming.

Wennekers, S. and M. Folkeringa (2002), The development of the business ownership rate in the Netherlands 1899-1998; a decomposition into sector shift and within sector trends, Paper presented at BKERC 2002 Conference, Boulder, Colorado.

Wennekers, Sander and Roy Thurik (1999), "Linking entrepreneurship and economic growth," Small Business Economics 13, 27-55.

Wennekers, S., A. van Stel, R. Thurik and P. Reynolds (2005), "Nascent Entrepreneurship and the Level of Economic Development", Small Business Economics 24 (3), 293-309.

Wit, G. de (1993), "Models of Self-Employment in a Competitive Market," Journal of Economic Surveys 7, 367-397.

Wubben, E.M. (1993), Markets, uncertainty and decision making: a history of the introduction of uncertainty into economics. Amsterdam: Thesis Publishers.

Yamada, G. (1996), "Urban informal employment and self-employment in developing countries: theory and evidence," Economic Development and Cultural Change 44, 289-314. 
Table 1 Uncertainty encompassing risk and opportunity

\begin{tabular}{|c|c|c|c|}
\hline $\begin{array}{r}\text { degree of } \\
\text { uncertainty }\end{array}$ & $\begin{array}{l}\text { (1) } \\
\text { possible outcomes and } \\
\text { their probabilities are } \\
\text { known }\end{array}$ & $\begin{array}{l}\text { (2) } \\
\text { there is a notion of } \\
\text { possible outcomes } \\
\text { and probabilities }\end{array}$ & $\begin{array}{l}\text { (3) } \\
\text { anything might happen }\end{array}$ \\
\hline $\begin{array}{l}\text { possibility of damage, loss or } \\
\text { failure }\end{array}$ & calculated risks & $\begin{array}{c}\text { perceived risks and } \\
\text { opportunity costs }\end{array}$ & $\begin{array}{c}\text { true uncertainty of loss } \\
\text { or failure }\end{array}$ \\
\hline $\begin{array}{l}\text { opportunity of profit or other } \\
\text { business success }\end{array}$ & expected profits & $\begin{array}{l}\text { perceived profit } \\
\text { opportunities }\end{array}$ & $\begin{array}{l}\text { true uncertainty of } \\
\text { profit; serendipity }\end{array}$ \\
\hline
\end{tabular}


Table 2 Major explanatory variables of the business ownership rate

\begin{tabular}{|c|c|c|}
\hline $\begin{array}{l}\text { Economic variables } \\
\text { (operationalization) }\end{array}$ & Relevant literature & Data availability (years); Source \\
\hline $\begin{array}{l}\text { level of economic development } \\
\text { (GDP per capita) }\end{array}$ & $\begin{array}{l}\text { Kuznets, 1971; Lucas, 1978; } \\
\text { Schultz, 1990; Yamada, } 1996\end{array}$ & $\begin{array}{l}\text { 1972, 1986, 2000; OECD National } \\
\text { Accounts }\end{array}$ \\
\hline $\begin{array}{l}\text { share of services (employment in } \\
\text { services divided by total labor force) }{ }^{1}\end{array}$ & van Stel and Carree, 2004 & $\begin{array}{l}\text { 1972, 1986, 2000; OECD National } \\
\text { Accounts }\end{array}$ \\
\hline $\begin{array}{l}\text { entrepreneurial income relative to the } \\
\text { wage rate (labor income share) }\end{array}$ & Parker, 2004 & $\begin{array}{l}\text { 1972, 1986, 2000; own calculations, } \\
\text { based on OECD National Accounts }\end{array}$ \\
\hline unemployment rate & $\begin{array}{l}\text { Evans and Leighton, 1989; } \\
\text { Meager, } 1992\end{array}$ & $\begin{array}{l}\text { 1972, 1986, 2000; OECD Main } \\
\text { Economic Indicators }\end{array}$ \\
\hline $\begin{array}{l}\text { social security entitlements } \\
\text { (unemployment replacement rate) }\end{array}$ & Parker and Robson, 2004 & $\begin{array}{l}\text { 1972, 1986, 2000; OECD Benefits and } \\
\text { Wages }\end{array}$ \\
\hline income disparity (Gini coefficient) ${ }^{3}$ & Ilmakunnas et al., 1999 & mid-1980s; 2000; OECD \\
\hline $\begin{array}{l}\text { cost of capital (long term interest } \\
\text { rate) }{ }^{4}\end{array}$ & Parker, 2004 & $\begin{array}{l}\text { 1991; 2000; OECD Economic Outlook } \\
78 \text { database }\end{array}$ \\
\hline assets; collateral (house prices) & $\begin{array}{l}\text { Evans and Jovanovic, 1989; } \\
\text { Evans and Leighton, 1989; } \\
\text { Parker, } 2004 .\end{array}$ & $\begin{array}{l}\text { insufficient data on house prices } \\
\text { available }\end{array}$ \\
\hline \multicolumn{3}{|l|}{ demographic variables } \\
\hline $\begin{array}{l}\text { age composition (number of people } \\
\text { aged } 25-39 \text { years divided by number } \\
\text { of people aged } 25-64 \text { ) }\end{array}$ & $\begin{array}{l}\text { Storey, 1994; Blanchflower et } \\
\text { al., } 2001\end{array}$ & $\begin{array}{l}\text { 1971, 1984, 1991; US Census Bureau, } \\
\text { International Data Base }\end{array}$ \\
\hline population density & $\begin{array}{l}\text { Audretsch and Keilbach, } \\
\text { 2004; Bais et al., } 1995\end{array}$ & $\begin{array}{l}\text { 1972, 1986, 2000; OECD Labour Force } \\
\text { Statistics (population), Grote Winkler } \\
\text { Prins encyclopaedia (area) }\end{array}$ \\
\hline $\begin{array}{l}\text { educational levels (gross enrollment } \\
\text { rates for secondary and tertiary } \\
\text { education) }\end{array}$ & $\begin{array}{l}\text { Delmar and Davidsson, 2000; } \\
\text { Uhlaner and Thurik, } 2007\end{array}$ & $\begin{array}{l}\text { 1970, 1985, 2000; World Bank EdStats } \\
\text { data base }\end{array}$ \\
\hline female labor participation & $\begin{array}{l}\text { Delmar and Davidsson, 2000; } \\
\text { Verheul, } 2005 .\end{array}$ & $\begin{array}{l}\text { 1972, 1986, 2000; OECD Labour Force } \\
\text { Statistics }\end{array}$ \\
\hline
\end{tabular}

${ }^{1}$ The services sector is broadly defined here, it contains the sectors Wholesale and retail trade, restaurants and hotels; Transport, storage and communication; Finance, insurance, real estate and business services; and Community, social and personal services.

${ }^{2}$ The labor income share has been corrected for the imputed wage income of self-employed individuals. To make the variable better fitting with the (non-agricultural) business ownership rate, the labor income share has been computed excluding the agricultural sector.

${ }^{3}$ No data available for 1972. Missing values for Belgium and Spain.

${ }^{4}$ No data available for 1972 . 
Table 3: Correlation matrix

\begin{tabular}{|c|c|c|c|c|c|c|c|c|c|c|c|c|c|c|}
\hline & 1 & 2 & 3 & 4 & 5 & 6 & 7 & 8 & 9 & 10 & 11 & 12 & 13 & 14 \\
\hline 1. Business ownership rate & 1 & & & & & & & & & & & & & \\
\hline 2. Uncertainty avoidance & $.49 * *$ & 1 & & & & & & & & & & & & \\
\hline 3. GDP per Capita & $-.24 \#$ & $-.38 * *$ & 1 & & & & & & & & & & & \\
\hline 4. Labor income share & $-.42 * *$ & $-.42 * *$ & $.27 *$ & 1 & & & & & & & & & & \\
\hline 5. Unemployment & $.31 *$ & .09 & -.01 & -.10 & 1 & & & & & & & & & \\
\hline 6. Female labor share & -.21 & -.22 & $.67 * *$ & .19 & .001 & 1 & & & & & & & & \\
\hline 7. Population density & -.03 & $.28 *$ & .04 & $.22 \#$ & -.01 & -.14 & 1 & & & & & & & \\
\hline 8. Share services & $.21 \#$ & $-.26 *$ & $.54 * *$ & .10 & -.02 & .18 & -.07 & 1 & & & & & & \\
\hline 9. Replacement rate unempl. & $-.26 *$ & -.18 & $.32 *$ & .05 & .14 & $.30 *$ & $.27 *$ & -.035 & 1 & & & & & \\
\hline 10. Gini index & $.71 * *$ & $.42 * *$ & -.21 & $-.35 *$ & $.32 \#$ & $-.32 \#$ & -.06 & $.33 *$ & $-.54 * *$ & 1 & & & & \\
\hline 11. Long term interest rate & .08 & -.14 & $-.56 * *$ & -.08 & $.38 *$ & $-.36 *$ & -.24 & -.25 & -.04 & -.26 & 1 & & & \\
\hline $\begin{array}{l}\text { 12. Share age group } 25-39 \text { in adult pop. } \\
(25-64 \mathrm{yr})\end{array}$ & .05 & $-.23 \#$ & $.42 * *$ & -.15 & .18 & $.32 *$ & -.15 & $.49 * *$ & $.29 *$ & -.11 & $.27 \#$ & 1 & & \\
\hline 13. Secondary education & -.06 & $-.23 \#$ & $.59 * *$ & .13 & .18 & $.64 * *$ & .10 & $.26 *$ & $.48 * *$ & -.21 & $-.48 * *$ & $.27 *$ & 1 & \\
\hline 14. Tertiary education & .06 & -.16 & $.73 * *$ & -.01 & $.27 *$ & $.66 * *$ & -.13 & $.44 * *$ & $.30 *$ & .11 & $-.60 * *$ & $.38 * *$ & $.70 * *$ & 1 \\
\hline$N$ & 63 & 63 & 63 & 63 & 63 & 63 & 63 & 63 & 63 & 37 & 40 & 63 & 62 & 62 \\
\hline MEAN & 0.11 & 62.9 & 14,762 & .77 & .056 & .39 & 1.20 & .42 & .25 & 0.29 & 0.074 & 0.43 & 0.96 & 0.36 \\
\hline STANDARD DEVIATION & 0.035 & 24.7 & 4,770 & .06 & .038 & .059 & 1.12 & .12 & .14 & 0.044 & 0.025 & 0.033 & 0.23 & 0.20 \\
\hline
\end{tabular}

Note: Correlations are based on a pooled sample of 1976, 1990 and 2004 (63 observations maximum).

$\# \mathrm{p}<0.10 ; * \mathrm{p}<0.05 ; * * \mathrm{p}<0.01$ 
Table 4: The direct influence of uncertainty avoidance on business ownership, pooled sample 1976, 1990 and 2004 ( 21 countries)

\begin{tabular}{|c|c|c|c|c|c|c|c|c|c|c|c|c|c|c|}
\hline & $\begin{array}{l}\text { base } \\
\text { model }\end{array}$ & & & & & & & & & & & & & $\begin{array}{c}\text { com- } \\
\text { plete } \\
\text { mo- } \\
\text { del }\end{array}$ \\
\hline \multirow[t]{2}{*}{ Constant } & .11 & .18 & .10 & .18 & .11 & .076 & .13 & .001 & .043 & .026 & .14 & .11 & .098 & .094 \\
\hline & (7.0) & (3.8) & $(4.6)$ & $(5.0)$ & $(7.0)$ & $(4.5)$ & (7.7) & $(0.0)$ & $(0.9)$ & $(0.6)$ & (4.4) & $(7.0)$ & (1.8) & $(5.0)$ \\
\hline \multirow{2}{*}{$\begin{array}{l}\text { Uncertainty } \\
\text { Avoidance }\end{array}$} & .041 & .036 & .043 & .036 & .048 & .045 & .031 & .009 & .041 & .044 & .036 & .043 & .035 & .038 \\
\hline & (3.1) & (2.9) & $(3.0)$ & $(2.4)$ & $(3.5)$ & $(3.9)$ & $(2.4)$ & $(0.4)$ & $(2.2)$ & (3.6) & $(2.7)$ & (3.3) & (2.4) & (3.3) \\
\hline \multirow[t]{2}{*}{ GDP per Capita } & -.38 & -.32 & -.32 & -.29 & -.35 & -.59 & -.39 & -.29 & -.26 & -.43 & -.37 & -.40 & -.50 & -.57 \\
\hline & (3.9) & (2.8) & (2.6) & (2.6) & $(3.8)$ & $(7.2)$ & $(4.8)$ & (1.8) & $(2.0)$ & $(4.3)$ & (3.9) & $(4.1)$ & (4.6) & (7.0) \\
\hline \multirow{2}{*}{$\begin{array}{l}\text { Labor income } \\
\text { share }\end{array}$} & & -.089 & & & & & & & & & & & & \\
\hline & & (1.3) & & & & & & & & & & & & \\
\hline \multirow[t]{2}{*}{ Unemployment } & & & .13 & & & & & & & & & & & \\
\hline & & & $(1.1)$ & & & & & & & & & & & \\
\hline \multirow{2}{*}{$\begin{array}{l}\text { Female labor } \\
\text { share }\end{array}$} & & & & -.21 & & & & & & & & & -.13 & \\
\hline & & & & $(2.6)$ & & & & & & & & & $(1.5)$ & \\
\hline \multirow{2}{*}{$\begin{array}{l}\text { Population } \\
\text { density }\end{array}$} & & & & & -.004 & & & & & & & & & \\
\hline & & & & & $(1.4)$ & & & & & & & & & \\
\hline \multirow[t]{2}{*}{ Share services } & & & & & & .15 & & & & & & & .10 & .14 \\
\hline & & & & & & $(5.4)$ & & & & & & & (3.1) & (4.6) \\
\hline \multirow{2}{*}{$\begin{array}{l}\text { Replacement } \\
\text { rate unempl. }\end{array}$} & & & & & & & -.082 & & & & & & -.063 & -.052 \\
\hline & & & & & & & (3.6) & & & & & & $(2.8)$ & $(2.2)$ \\
\hline \multirow[t]{2}{*}{ Gini index } & & & & & & & & .51 & & & & & & \\
\hline & & & & & & & & $(4.8)$ & & & & & & \\
\hline \multirow{2}{*}{$\begin{array}{l}\text { Long term } \\
\text { interest rate }\end{array}$} & & & & & & & & & .78 & & & & & \\
\hline & & & & & & & & & $(2.2)$ & & & & & \\
\hline \multirow{2}{*}{$\begin{array}{l}\text { Share age group } \\
25-39 \text { in adult } \\
\text { pop. (25-64 yr) }\end{array}$} & & & & & & & & & & .22 & & & .12 & \\
\hline & & & & & & & & & & (2.0) & & & (1.0) & \\
\hline \multirow{2}{*}{$\begin{array}{l}\text { Secondary } \\
\text { education }\end{array}$} & & & & & & & & & & & -.025 & & & \\
\hline & & & & & & & & & & & $(0.8)$ & & & \\
\hline \multirow{2}{*}{$\begin{array}{l}\text { Tertiary } \\
\text { education }\end{array}$} & & & & & & & & & & & & .031 & & \\
\hline & & & & & & & & & & & & (1.1) & & \\
\hline \multirow{2}{*}{$\begin{array}{l}\text { Year dummy } \\
1990\end{array}$} & .023 & .022 & .015 & .033 & .023 & .023 & .032 & & & .018 & .026 & .019 & .033 & .029 \\
\hline & (2.8) & (2.4) & $(1.3)$ & (3.3) & $(2.7)$ & (3.3) & (3.9) & & & (1.9) & (2.4) & $(2.1)$ & $(3.2)$ & (3.8) \\
\hline \multirow{2}{*}{$\begin{array}{l}\text { Year dummy } \\
2004\end{array}$} & .046 & .041 & .037 & .060 & .044 & .048 & .059 & .009 & .051 & .045 & .055 & .034 & .065 & .055 \\
\hline & $(4.3)$ & (3.4) & (2.9) & $(4.5)$ & $(4.2)$ & $(6.1)$ & (5.9) & $(0.9)$ & (3.3) & $(4.1)$ & (3.3) & $(2.5)$ & $(4.9)$ & (7.0) \\
\hline $\mathrm{N}$ & 63 & 63 & 63 & 63 & 63 & 63 & 63 & 37 & 40 & 63 & 62 & 62 & 63 & 63 \\
\hline $\mathrm{R}^{2}$ & .368 & .385 & .381 & .429 & .383 & .567 & .459 & .592 & .361 & .399 & .377 & .373 & .627 & .601 \\
\hline
\end{tabular}


Table 5: The direct influence of uncertainty avoidance on business ownership, separate samples 1976, 1990 and 2004 ( 21 countries)

\begin{tabular}{|c|c|c|c|c|c|c|}
\hline & 1976 & 1976 & 1990 & 1990 & 2004 & 2004 \\
\hline \multirow[t]{2}{*}{ Constant } & .093 & $.060 *$ & $.16 \#$ & $.14 * *$ & $.32 \#$ & $.33 \#$ \\
\hline & (1.4) & $(2.2)$ & (1.9) & $(3.4)$ & (1.8) & $(2.0)$ \\
\hline \multirow[t]{2}{*}{ Uncertainty Avoidance } & $.054 \#$ & $.063 * *$ & .029 & .032 & -.007 & -.0095 \\
\hline & $(1.9)$ & $(3.1)$ & (1.3) & (1.4) & $(0.4)$ & $(0.6)$ \\
\hline \multirow[t]{2}{*}{ GDP per Capita } & -.39 & $-.52 *$ & $-.63 * *$ & $-.58 * *$ & $-.62 * *$ & $-.59 * *$ \\
\hline & (1.3) & (2.7) & $(3.0)$ & $(3.1)$ & $(4.4)$ & $(4.0)$ \\
\hline \multirow[t]{2}{*}{ Female labor share } & -.15 & & .041 & & -.59 & $-.67 \#$ \\
\hline & (1.3) & & $(0.3)$ & & (1.5) & $(2.0)$ \\
\hline \multirow[t]{2}{*}{ Share services } & .11 & $.15 *$ & $.16 *$ & $.13 *$ & .047 & \\
\hline & (1.5) & $(2.2)$ & $(2.2)$ & (2.7) & $(0.7)$ & \\
\hline \multirow{2}{*}{$\begin{array}{l}\text { Replacement rate } \\
\text { unemployment }\end{array}$} & -.030 & & -.093 & $-.10 *$ & -.056 & $-.072 *$ \\
\hline & $(0.8)$ & & $(1.7)$ & $(2.3)$ & $(1.5)$ & $(2.3)$ \\
\hline \multirow{2}{*}{$\begin{array}{l}\text { Share age group } 25-39 \text { in } \\
\text { adult pop. (25-64 yr) }\end{array}$} & .066 & & -.091 & & .40 & $.50 * *$ \\
\hline & $(0.6)$ & & $(0.5)$ & & (1.7) & $(3.2)$ \\
\hline $\mathrm{N}$ & 21 & 21 & 21 & 21 & 21 & 21 \\
\hline $\mathrm{R}^{2}$ & .614 & .558 & .749 & .747 & .686 & .672 \\
\hline
\end{tabular}

Dependent variable: number of non-agricultural business owners per labor force.

Absolute heteroskedasticity consistent $\mathrm{t}$-values are between brackets.

$\# \mathrm{p}<0.10 ; * \mathrm{p}<0.05 ; * * \mathrm{p}<0.01$. 
Table 6: The indirect influence of uncertainty avoidance on business ownership, pooled samples 1976, 1990 and 2004 ( 21 countries); base model using UAI and per capita income only

\begin{tabular}{|c|c|c|c|c|}
\hline & \multicolumn{2}{|c|}{ UAI continuous effect } & \multicolumn{2}{|c|}{ UAI discrete effect } \\
\hline Constant & $\begin{array}{l}.11 * * \\
(7.0)\end{array}$ & $\begin{array}{c}.064 * \\
(2.6)\end{array}$ & $\begin{array}{l}.14 * * \\
(8.2)\end{array}$ & $\begin{array}{l}.12 * * \\
(7.9)\end{array}$ \\
\hline Uncertainty Avoidance (UAI) & $\begin{array}{c}.041 * * \\
(3.1)\end{array}$ & $\begin{array}{c}.11 * * \\
(2.9)\end{array}$ & & \\
\hline Dummy UAI strong & & & $\begin{array}{c}.016 \# \\
(1.8)\end{array}$ & $\begin{array}{l}.060 * \\
(2.5)\end{array}$ \\
\hline GDP per Capita (YCAP) & $\begin{array}{c}-.38 * * \\
(3.9)\end{array}$ & $\begin{array}{l}-.017 \\
(0.1)\end{array}$ & $\begin{array}{c}-.42 * * \\
(3.5)\end{array}$ & $\begin{array}{c}-.28 * * \\
(2.8)\end{array}$ \\
\hline $\mathrm{UAI} * \mathrm{YCAP}$ & & $\begin{array}{c}-.53 \# \\
(1.8)\end{array}$ & & \\
\hline Dummy UAI strong * YCAP & & & & $\begin{array}{c}-.31 \# \\
(1.8)\end{array}$ \\
\hline Year dummy 1990 & $\begin{array}{c}.023 * * \\
(2.8)\end{array}$ & $\begin{array}{c}.022 * * \\
(2.7)\end{array}$ & $\begin{array}{c}.025 * * \\
(2.8)\end{array}$ & $\begin{array}{c}.024 * * \\
(2.8)\end{array}$ \\
\hline Year dummy 2004 & $\begin{array}{c}.046 \text { ** } \\
(4.3)\end{array}$ & $\begin{array}{c}.043 * * \\
(4.1)\end{array}$ & $\begin{array}{c}.050 * * \\
(4.2)\end{array}$ & $\begin{array}{c}.047 * * \\
(4.3)\end{array}$ \\
\hline $\mathrm{N}$ & 63 & 63 & 63 & 63 \\
\hline $\mathrm{R}^{2}$ & .368 & .400 & .347 & .383 \\
\hline Loglikelihood & 137.3 & 139.0 & 136.3 & 138.1 \\
\hline
\end{tabular}

Dependent variable: number of non-agricultural business owners per labor force.

Absolute heteroskedasticity consistent t-values are between brackets.

$\# \mathrm{p}<0.10 ; * \mathrm{p}<0.05 ; * * \mathrm{p}<0.01$. 
Table 7: The indirect influence of uncertainty avoidance on business ownership, pooled samples 1976, 1990 and 2004 ( 21 countries), complete model

\begin{tabular}{|c|c|c|c|c|}
\hline \multirow[b]{2}{*}{ Constant } & \multicolumn{2}{|c|}{ UAI continuous effect } & \multicolumn{2}{|c|}{ UAI discrete effect } \\
\hline & $\begin{array}{c}.094 * * \\
(5.0)\end{array}$ & $\begin{array}{c}.058 * \\
(2.0)\end{array}$ & $\begin{array}{c}.11 * * \\
(6.8)\end{array}$ & $\begin{array}{c}.093 * * \\
(5.3)\end{array}$ \\
\hline Uncertainty Avoidance (UAI) & $\begin{array}{c}.038 * * \\
(3.3)\end{array}$ & $\begin{array}{c}.089 * \\
(2.6)\end{array}$ & & \\
\hline Dummy UAI strong & & & $\begin{array}{c}.022 * * \\
(2.9)\end{array}$ & $\begin{array}{l}.048 * \\
(2.2)\end{array}$ \\
\hline GDP per Capita (YCAP) & $\begin{array}{c}-.57 * * \\
(7.0)\end{array}$ & $\begin{array}{c}-.31 * \\
(1.8)\end{array}$ & $\begin{array}{c}-.59 * * \\
(6.8)\end{array}$ & $\begin{array}{c}-.50 * * \\
(5.5)\end{array}$ \\
\hline $\mathrm{UAI} * \mathrm{YCAP}$ & & $\begin{array}{l}-.38 \\
(1.5)\end{array}$ & & \\
\hline Dummy UAI strong $*$ YCAP & & & & $\begin{array}{l}-.18 \\
(1.1)\end{array}$ \\
\hline Share services & $\begin{array}{c}.14 * * \\
(4.6)\end{array}$ & $\begin{array}{c}.14 * * \\
(4.6)\end{array}$ & $\begin{array}{c}.15 * * \\
(5.5)\end{array}$ & $\begin{array}{c}.15 * * \\
(5.3)\end{array}$ \\
\hline Replacement rate unemployment & $\begin{array}{c}-.052 * \\
(2.2)\end{array}$ & $\begin{array}{c}-.047 * \\
(1.9)\end{array}$ & $\begin{array}{c}-.052 * \\
(2.5)\end{array}$ & $\begin{array}{c}-.046 * \\
(2.0)\end{array}$ \\
\hline Year dummy 1990 & $\begin{array}{c}.029 * * \\
(3.8)\end{array}$ & $\begin{array}{c}.027 * * \\
(3.6)\end{array}$ & $\begin{array}{c}.028 * * \\
(3.9)\end{array}$ & $\begin{array}{c}.027 * * \\
(3.6)\end{array}$ \\
\hline Year dummy 2004 & $\begin{array}{c}.055 * * \\
(7.0)\end{array}$ & $\begin{array}{c}.052 * * \\
(6.1)\end{array}$ & $\begin{array}{c}.055 * * \\
(7.2)\end{array}$ & $\begin{array}{c}.053 * * \\
(6.5)\end{array}$ \\
\hline $\mathrm{N}$ & 63 & 63 & 63 & 63 \\
\hline $\mathrm{R}^{2}$ & .601 & .617 & .617 & .629 \\
\hline Loglikelihood & 151.8 & 153.1 & 153.1 & 154.1 \\
\hline
\end{tabular}

Dependent variable: number of non-agricultural business owners per labor force.

Absolute heteroskedasticity consistent $\mathrm{t}$-values are between brackets.

$\# \mathrm{p}<0.10 ; * \mathrm{p}<0.05 ; * * \mathrm{p}<0.01$. 